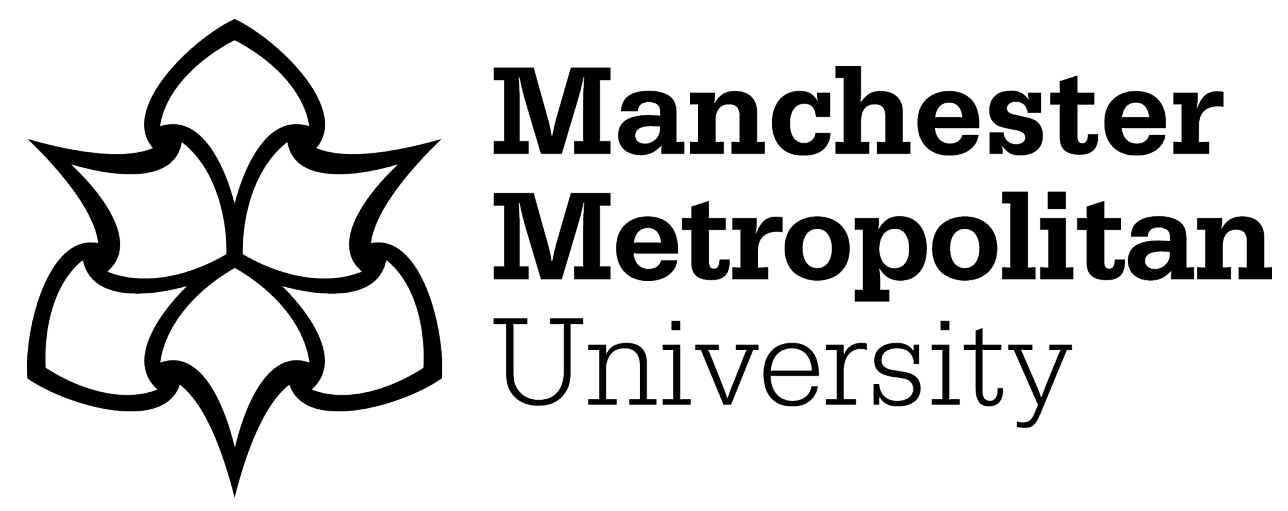

Strickland, Lloyd ORCID logoORCID: https://orcid.org/0000-0003-2560-6909 (2021) Book review: "The New Atheism, Myth, and History: The Black Legends of Contemporary Anti-Religion" by Nathan Johnstone. Numen, 68 (2-3). pp. 303-305. ISSN 0029-5973

Downloaded from: https://e-space.mmu.ac.uk/625817/

Version: Accepted Version

Publisher: Brill Academic Publishers

DOI: https://doi.org/10.1163/15685276-12341625

Please cite the published version 
Nathan Johnstone, The New Atheism, Myth, and History: The Black Legends of Contemporary Anti-Religion. Cham: Palgrave, 2018, pp. xiv + 309, ISBN: 978-3-319-894553 (Hbk).

Born in the aftermath of $9 / 11$, the New Atheist movement has sought to promote the perceived virtues of atheism and castigate the perceived vices of religion, with the aim, or at least the hope, that atheism would one day triumph and leave religion in the dustbin of history. In their assault on religion, New Atheist authors such as Sam Harris, Richard Dawkins, and Christopher Hitchens (as well as sympathizers such as Michel Onfray, Hector Avelos, and Victor Stenger) have drawn upon resources from many disciplines, most notably politics, sociology, philosophy, cultural studies, criminology, and history. While the (many) shortcomings of New Atheist arguments in many of these disciplines were quickly identified and challenged in a slew of journal articles and books, their use (or misuse) of history largely escaped scrutiny. This changed in 2014 with Borden W. Painter Jr.'s The New Atheist Denial of History (New York: Palgrave), which sought to challenge and correct the New Atheists' use of historical evidence and arguments. To that we may now add Johnstone's The New Atheism, Myth, and History: The Black Legends of Contemporary Anti-Religion. Although the two works cover similar ground, with both seeking to juxtapose the New Atheist reading of history with that of mainstream historians in order to show that the New Atheists typically offer little more than a caricature, they differ in many other ways. Johnstone's book is considerably longer, by more than 100 pages, and offers correspondingly more detail, and while Painter opts for a reverse chronological approach, starting with the twentieth century and working backwards to late antiquity, Johnstone opts for a more thematic approach, devoting entire chapters to specific historical events or characters that New Atheists have sought to exploit for their polemical aims.

In addition to a standalone introduction, Johnstone's book is divided into three parts, each consisting of two, three, or four chapters. In part 1, "Black Legends," Johnstone examines three cases of "gross exaggeration" (17) employed by New Atheists to ground their claim that religion is inherently malevolent: early modern European witch-hunts, cases of religious persecution, such as that of the Cathars and the Inquisition, and lastly the Holocaust, which New Atheists typically present as the natural result of Hitler's religiosity. Across these richly-detailed chapters, Johnstone eloquently complicates, disrupts, and often successfully undermines the all-too-simplistic historical narratives offered by various New Atheist authors. Johnstone notes, for example, that the majority of witch trials occurred in specific 
geographical areas of the Holy Roman Empire (the archbishoprics of Trier, Mainz, Cologne, the bishoprics of Bamberg and Würzburg, and the town of Ellwangen) rather than Europe as a whole, and in specific time periods (mainly 1588-1639) rather than the entire history of Christendom, which suggests specific cultural and political conditions that provoked the witch-hunting craze in these places at these times (30).

In part 2, "Minds in Opposition," Johnstone considers a clutch of New Atheist "heroes" from history, such as the Greek atomists Leucippus and Democritus, vaunted for their materialism by Hitchens, Onfray, and Stenger, as well as two sixteenth- and seventeenth-century opponents of witch-trials, Dietrich Flade and Friedrich Spee, held up by Sam Harris as models of rational scepticism in an age of superstition. Here Johnstone systematically shows that the characters are far from being role models for New Atheist rationalism. Spee, for example, was not the opponent of common prejudices and superstitions as Harris presents him, but rather a demonological conservative who saw torture as a demonic invention, witch-hunting officials as satanic agents, and the witch-trials as the means by which Satan subverted communal harmony. As Johnstone observes, Spee "was an opponent of witch-hunting, not because he was possessed of a rationality more like ours, but because he, quite literally, thought it was the work of the Devil” (173).

In part 3, "The Innocence of Atheism," Johnstone challenges New Atheist claims of the moral superiority of unbelief. Particularly notable here is chapter 7, in which Johnstone carefully charts the ways that atheism informed Soviet attempts to rid the state of religion, which serves to counteract clumsy New Atheist claims that atheism has not (and cannot be) implicated in oppression and persecution.

An important feature of Johnstone's book is its identification of some of the favored sources of the New Atheists, which often turn out to be discredited nineteenth-century texts, such as Charles Mackay's Extraordinary Popular Delusions and the Madness of Crowds (1841) or Andrew Dickson White's A History of the Warfare of Science with Theology (1896), rather than more credible modern sources, which are typically ignored. However, in this matter, Johnstone's book is not the equal of Painter Jr.'s, which contains a more extensive exposé of the historical sources used - or missed - by New Atheists (see his The New Atheist Denial of History, pp16-18, 34-36, 66-67, 80-84, 88, 111, and 132-145). However, notwithstanding the thinner discussion of the New Atheists' poor use of historical sources, Johnstone's book is overall the richer, offering more historical detail and considering (and combating) a greater number of New Atheist claims. While both books may be profitably read side-by-side, Johnstone's is easier to recommend not just for the depth of its 
scholarship, but also for the meticulousness of its arguments and the eloquence with which they are presented. That it contains no significant discussion of the Crusades, despite the fact that New Atheists often appeal to them in their polemic, is not a weakness, at least comparatively speaking, since Painter Jr.'s book has little to say about them either.

Although Johnstone's book is an impressive work in its own right, I do have one reservation, which concerns not the message so much as the medium. As is well-known, the New Atheist arguments were initially circulated and popularized in a number of mass-market books and have since been repeated countless times via the internet, in atheist groups and forums and through various social media channels etc. This has given them considerable reach and influence, which unfortunately Johnstone's book is unlikely to be able to match. For while his corrective is worthwhile, welcome, and valuable in itself, the fact that it is very different in style (scholarly vs. popular) and offered in a substantial book whose price will limit the readership even further, likely means that its effectiveness is combating the spread of New Atheist "myths" will likewise be limited. There is, of course, a broad problem of how to combat falsehoods or misconceptions that have become widely accepted as facts through sheer frequency of repetition or by the volume at which they are articulated, and while academics may be loathe to admit it, the scholarly monograph alone is perhaps not the most effective way to do it.

\section{Lloyd Strickland}

Manchester Metropolitan University

L.Strickland@mmu.ac.uk 